\title{
Study on Construction of Practical Teaching System of E - commerce Major in Higher Vocational Colleges
}

\author{
Xiaowei Ma \\ Jiangsu College of Finance \& Accounting, China
}

\begin{abstract}
Keywords: Colleges; E-commerce; Practical teaching; Teaching system
\end{abstract}
\begin{abstract}
E-commerce activities are developing rapidly, and e-commerce itself is a course with strong practicality and operability. Practical teaching is an important part of e-commerce teaching, and a significant teaching link to cultivate students to understand the society and improve their application ability and operational skills. The well-established e-commerce practice teaching system is an important guarantee for teaching of e-commerce courses. Jiangsu College of Finance \& Accounting is taken as an example in this paper to explore the thoughts of practical teaching system construction for e-commerce major in higher vocational colleges against the specific practices of e-commerce in practical teaching process, hoping to have some positive effects.
\end{abstract}

\section{Research Background}

The rapid development of e-commerce makes the demand for e-commerce professionals increase dramatically. Higher vocational colleges, as one type of higher education, take the cultivation of higher technical professionals who meet the requirements for management, production, construction and service forefront as their aim of running a school. In recent years, they have obtained rapid development in the construction of e-commerce major. The graduates of Jiangsu College of Finance \& Accounting are more proficient in practice operational skills although their theoretical knowledge is not as solid and profound as that of ordinary undergraduate college graduates. Therefore, building a set of effective professional practice teaching curriculum system in combination with their own background and characteristics is the problem to be solved for development of e-commerce major of Jiangsu College of Finance \& Accounting.

\section{Combine Theory with Practice, and Divide Curriculum System Scientifically}

In order to reflect the coherence, phase and practicality of the curriculum system, the teachers of e-commerce major of our school divide the courses into three categories, namely technology, business and management, according to the requirements of syllabus. Students' sense of identity toward this major can be cultivated through strong professional culture edification; help students to make clear their learning objectives, to accept advanced learning methods, and form the overall understanding of theoretical learning and practical skills. As for the design of practical teaching, the basic learning rules shall be followed, that is, from easy to difficult and from simple to complex, with simulation training as the main activities at early stage. We have purchased the teaching software and platform such as "e-commerce simulation teaching software", "customer relationship management teaching software", providing students with essential electronic business simulation training space. For computer technology courses, our school requires students to be able to solve specific issues with specific methods, and can design, make webpage, develop and build website and so on. With respect to business courses, make endeavor to create a real Internet environment as the training background. For example, network marketing courses, in addition to the auxiliary teaching software, mastering of the most basic means, techniques and methods, at the same time, we encourage and require students to shop online and set up online shop, requiring students to finish independently each link from survey, communication, procurement to sell. Meanwhile, take advantage of the school - enterprise cooperation opportunities to organize students to observe and practice in the relevant units, call on them to practice in enterprises using holidays, thus to do something which are really related to the major. 


\section{Composition of Practical Teaching System}

Through the above scientific analysis, the practical teaching system of our school is determined as three specific links, namely, operation skills, post internship and on-duty practice:

Practical Operation Skills. Cultivate students' practical operation skills and encourage them to obtain corresponding vocational qualification certificates through computer network training, network marketing simulation training, web page design training, customer relationship management training and other practical operational links. At the same time, we also closely follow the development trend of China's e-commerce. Our school also introduced e-commerce logistics training courses to enable students to master the operation skills of taking delivery of goods, ordering, shipping and warehouse transfer in logistics and distribution process.

Post Internship. Enable students to understand and be familiar with the major, combine theory with practice, master and use the professional knowledge solidly and flexibly via such links as survey, communication, procurement and public relation through the e-commerce studio of our school (the unique training base of our school in terms of "introducing enterprises into school"), professional education, social survey, set up online shop.

On-Duty Practice. Take advantage of school-enterprise cooperation opportunities, organize students to practice on duty in relevant enterprises, so that students can make full use of the theoretical knowledge they have obtained in practice, and cultivate students' professional and technical ability comprehensively, to lay a solid foundation for them to be employed.

\section{Implementation of Practical Teaching System in Jiangsu College of Finance \& Accounting}

According to the above-mentioned exploration in combination with the actuality of Jiangsu College of Finance \& Accounting, our school offers 6 major practical courses for the e-commerce major, including e-commerce foundation and practice, e-commerce logistics, etc., and sets up teaching implementation plan (see Table 1- Main Practice Courses and Content Requirement of E - commerce Major), and arranges corresponding time planning (see Table 2 - Teaching Time Allocation Table of Practical Teaching Courses for E - commerce Major (allocated by week)). In addition to establishing the above practical curriculum system, teachers from our school will offer the following innovations to practical teaching using the existing teaching environment:

Make Full Use of Teaching Cases to Mobilize Students' Enthusiasm of Practice. The "case" should be seen as a means of teaching and teaching method, rather than the course itself in teaching. In the teaching process, teachers should make real cases run through introduction to e-commerce, e-commerce logistics, e-commerce site construction and related technical courses or other more courses, and avoid the students simply take teaching cases as "stories", knowing only the results, but being unable to solve practical problems using the knowledge they have gained. To teach using cases can stimulate students' enthusiasm of learning, so as to make them operate and think by themselves; at the same time, take advantage of the network information technology to explain the case, enabling students to have good exercises of their comprehensive quality, thus their ability of analyzing and solving practical problems is improved effectively.

Stimulate Students to Participate in Practical Activities Using Scientific Research Achievements. Pay attention to the combination of enterprises, universities and research in e-commerce teaching, introduce teachers' scientific research achievements actively and introduce the frontier situation of this field personally. For example, the teachers of e-commerce major of our school are developing national model textbook of "Customer Relationship Management Application". As a result, teachers can help students to make clear the important role of CRM in e-commerce activities while they are teaching, and demonstrate the vital task of information processing and knowledge acquisition in the business activity of CRM. The subject of professional teaching team, "Research and Practice of Higher Vocational Students' Online Business", has attracted students to actively participate in the survey, thus to stimulate and guide students to about their needs for starting up a business according to the survey 
results. This special teaching practice has not only increased students' interest in e-commerce practice, but also has improved their ability to integrate into society.

Table 1 Main Practice Courses and Content Requirements of E - commerce Major

\begin{tabular}{|c|c|c|c|}
\hline No. & Course & Main Teaching Content and Requirements & $\begin{array}{l}\text { Teaching } \\
\text { Implementation Plan }\end{array}$ \\
\hline 1 & $\begin{array}{l}\text { E-comm } \\
\text { erce } \\
\text { Foundati } \\
\text { on and } \\
\text { Practice } \\
(102)\end{array}$ & $\begin{array}{l}\text { (1) Learn about the basic concept, overall framework } \\
\text { and business model of e-commerce; master network } \\
\text { marketing-related technologies and strategies; learn } \\
\text { about the type and characteristics of online advertising; } \\
\text { learn about relevant environment in e-commerce, } \\
\text { including the technical issues, security issues, logistics } \\
\text { and distribution issues, payment issues and legal and } \\
\text { regulatory issues in e-commerce development; have a } \\
\text { good command of the operation flow of each module } \\
\text { of e - commerce lab software, and be able to apply the } \\
\text { skills they have gained to Taobao, Alibaba and other } \\
\text { well-known e-commerce sites creatively. } \\
\text { (2) Main teaching content: Project I Introduction to } \\
\text { E-commerce; Project II Experience Network } \\
\text { Marketing; Project III Online Payment and Security } \\
\text { Transactions; Project IV E-commerce Logistics } \\
\text { Analysis; Project V Typical Electronic Trading Model; } \\
\text { Project VI Actual Combat in Taobao. }\end{array}$ & $\begin{array}{l}\text { (1) Organize teaching in } \\
\text { combination with e - } \\
\text { commerce vocational } \\
\text { qualification assessment; } \\
\text { (2) To teach combining } \\
\text { with simulation training } \\
\text { platform equipped for } \\
\text { e-commerce engineer; } \\
\text { (3) Pay attention to the } \\
\text { demonstration of } \\
\text { advanced and typical } \\
\text { e-commerce platform in } \\
\text { teaching, and strengthen } \\
\text { the intuitive teaching } \\
\text { links. }\end{array}$ \\
\hline 2 & $\begin{array}{l}\text { Network } \\
\text { Marketin } \\
\mathrm{g} \text { and } \\
\text { Planning } \\
(64)\end{array}$ & $\begin{array}{l}\text { (1) Learn about the network marketing theory system, } \\
\text { grasp the basic theory and core content of network } \\
\text { marketing; be familiar with the network virtual market, } \\
\text { and the methods, tools, means and techniques for } \\
\text { conducting marketing activities; master the program } \\
\text { planning of network marketing and operation skills of } \\
\text { network marketing strategy. } \\
\text { (2) Main teaching content: Project I Understand } \\
\text { Network Marketing Environment; Project II Selection } \\
\text { of Network Marketing Tool; Project III Collection and } \\
\text { Publication of Network Business Information; Project } \\
\text { IV Network Market Survey, Project V Network } \\
\text { Promotion; Project VI Website Promotion; Project VII } \\
\text { Network Marketing Strategy Planning; Project VIII } \\
\text { Network Marketing Activities Planning }\end{array}$ & $\begin{array}{l}\text { (1) To teach and } \\
\text { evaluate by reference to } \\
\text { programs relating to } \\
\text { vocational education e - } \\
\text { commerce skills } \\
\text { competition; } \\
\text { (2) As the concept of } \\
\text { network marketing } \\
\text { updates quite fast, so the } \\
\text { new methods and new } \\
\text { ideas for this subject } \\
\text { shall be supplemented in } \\
\text { time; } \\
\text { (3) This course is of } \\
\text { strong practicalness, and } \\
\text { the enterprise projects } \\
\text { shall be introduced in as } \\
\text { teaching content. }\end{array}$ \\
\hline 3 & $\begin{array}{l}\text { Custome } \\
\mathrm{r} \\
\text { Relation } \\
\text { ship } \\
\text { Manage } \\
\text { ment } \\
(64)\end{array}$ & $\begin{array}{l}\text { Understand the connotation of customer } \\
\text { relationship management, master the main business } \\
\text { and process of customer relationship management; } \\
\text { master customer segmentation and management } \\
\text { strategy; understand the basic application of data } \\
\text { mining method in customer relationship. } \\
\text { (2) Main teaching content: Project I Post Cognition of }\end{array}$ & $\begin{array}{l}\text { Take specific "customer } \\
\text { management } \quad \text { and } \\
\text { customer service } \\
\text { project" as the platform } \\
\text { in teaching design, to } \\
\text { conduct the curriculum } \\
\text { design based on work }\end{array}$ \\
\hline
\end{tabular}




\begin{tabular}{|c|c|c|c|}
\hline & & 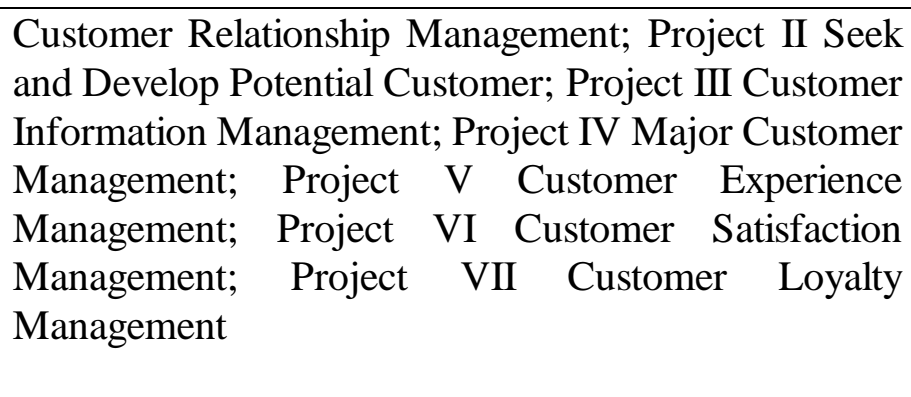 & $\begin{array}{l}\text { process and action } \\
\text { orientation, to form the } \\
\text { integrated course of } \\
\text { "teaching, learning and } \\
\text { doing" and conduct the } \\
\text { task driven teaching with } \\
\text { work process as } \\
\text { orientation. }\end{array}$ \\
\hline 4 & $\begin{array}{l}\text { Web } \\
\text { Design } \\
\text { and } \\
\text { Producti } \\
\text { on } \\
(96)\end{array}$ & $\begin{array}{l}\text { (1) Grasp the basic concept of web design, be able to } \\
\text { design and produce the common static web pages using } \\
\text { common web design software; understand the } \\
\text { common script language and master dynamic web } \\
\text { design initially. } \\
\text { (2) Main teaching content: Project I Introduction to } \\
\text { DreamWeaver; Project II Produce Web Pages with } \\
\text { Illustrations; Project III Page Layout Design; Project } \\
\text { IV CSS Style Design; Project V Form Application; } \\
\text { Project VI Use Behavior; Project VII Templates and } \\
\text { Library; Project VIII Integrated Operation of Static } \\
\text { Web Page }\end{array}$ & $\begin{array}{l}\text { (1) To teach and } \\
\text { evaluate by reference to } \\
\text { relevant programs of } \\
\text { vocational education e - } \\
\text { commerce skills } \\
\text { competition; } \\
\text { (2) The design of this } \\
\text { course reflects that it } \\
\text { takes "ability as } \\
\text { standard, professional } \\
\text { practice as the main line, } \\
\text { the project curriculum as } \\
\text { main body", selects } \\
\text { practical teaching case, } \\
\text { and integrates } \\
\text { knowledge used in web } \\
\text { design professional skills } \\
\text { into the project }\end{array}$ \\
\hline 5 & $\begin{array}{l}\mathrm{E} \\
\text { commer } \\
\text { ce } \\
\text { Logistics } \\
(68)\end{array}$ & $\begin{array}{l}\text { (1) Learn about the basic knowledge and theory of } \\
\text { e-commerce logistics system, understand the } \\
\text { characteristics of e-commerce logistics, and master the } \\
\text { operation skills in logistics delivery process, such as } \\
\text { taking delivery of goods, ordering, shipping and } \\
\text { warehouse transfer. } \\
\text { (2) Main teaching content: Project I Introduction to } \\
\text { E-commerce Logistics Technology; Project II } \\
\text { Enterprise Procurement and Supply Chain } \\
\text { Management; Project III Modern Sales and Returned } \\
\text { Logistics Management; Project IV Warehouse } \\
\text { Management and Inventory Control; Project V } \\
\text { E-commerce Distribution and Distribution Center; } \\
\text { Project VI Logistics Service and Cost Management }\end{array}$ & $\begin{array}{l}\text { Carry teaching in } \\
\text { combination } \\
\text { logistics } \\
\text { platform }\end{array}$ \\
\hline
\end{tabular}




\begin{tabular}{|c|c|c|c|}
\hline 6 & $\begin{array}{l}\text { Business } \\
\text { Informat } \\
\text { ion } \\
\text { Collectio } \\
\mathrm{n} \quad \text { and } \\
\text { Manage } \\
\text { ment } \\
(68)\end{array}$ & $\begin{array}{l}\text { (1) Learn about the basic knowledge of business } \\
\text { information collection, be familiar with the } \\
\text { development of network information collection } \\
\text { technology, master business information collection } \\
\text { method, master the methods of business information } \\
\text { collection and processing by tool software. } \\
\text { (2) Main teaching content: Project I Network } \\
\text { Information Classification; Project II Use of Network } \\
\text { Information Collection Tool Software; Project III } \\
\text { Network Information Collection and Screening; } \\
\text { Project IV Network Information Processing; Project V } \\
\text { Network Information Release }\end{array}$ & $\begin{array}{l}\text { Introduce in enterprise } \\
\text { projects as the teaching } \\
\text { content of this course }\end{array}$ \\
\hline
\end{tabular}

Table 2 Teaching Time Allocation Table of Practical Teaching Courses for E - commerce Major (allocated by week)

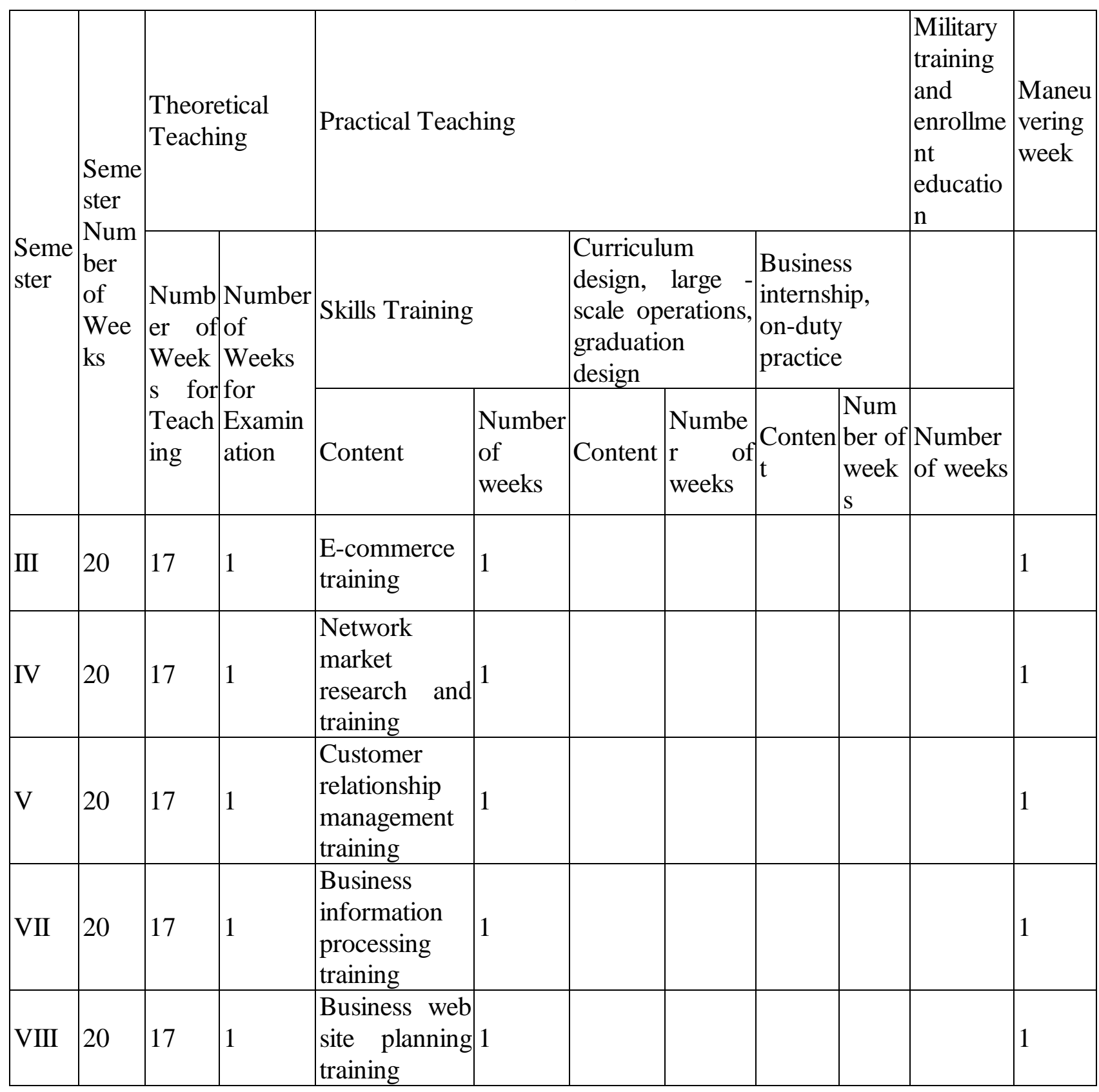




\begin{tabular}{|l|l|l|l|l|l|l|l|l|l|l|l|}
\hline X & 20 & & & & & $\begin{array}{l}\text { Graduat } \\
\text { e design }\end{array}$ & 4 & $\begin{array}{l}\text { Gradu } \\
\text { ation } \\
\text { practic } \\
\text { e }\end{array}$ & 14 & & 2 \\
\hline Total & 120 & 85 & 5 & & 5 & & 4 & & 14 & 1 & 7 \\
\hline
\end{tabular}

Introduce in Project Management Thought, and Improve Student's Practice Efficiency. In practice teaching activities, we shall encourage students to actively participate in various skill competitions and entrepreneurship contests of e-commerce, and consciously organize them to join in various skills competitions undertaken by teachers. Under the leadership of project host teacher, the participating students form a new research team, with clear division of labor, specific responsibilities. As a result, students can be personally on the scene, change passive to active with self-learning, and really become leading actor in learning; when the team members are competing in terms of the project, all of them cooperate by groups with mutual communication, which has reflected and cultivated their good team spirit. At the time of tackling difficulties, students' innovation ability can be cultivated through reorganization of knowledge modules. Teachers play a role of guiding and encouragement. Exchanging experiences between teachers and students will not only be conducive to the completion of competition, but also help students' practical ability to be improved continuously. In recent years, students of our school have participated in e-commerce entrepreneurship contests of all levels with excellent results. Since the first participation in competition by students of 2006 till now, we have won multiple provincial third prizes, a second prize and a first prize.

Mutual Exchange between School and Enterprise, and Enhance the Level of Teachers. In recent years, China's higher vocational colleges actively explore the new model of school-enterprise combination for school production training base construction through various attempts, which has expanded the intensity of on - campus productive training and off-campus practice, and has improved students' practical operation ability. After years of efforts, our school has constructed "E-commerce Studio" production practice base together with Lianyungang Xiangtian Technology Co., Ltd., creating an enterprise-level e-commerce operating environment for our school.

The studio has three-level management and operation mechanism with joint management of enterprises, teachers, and students, dominating by students' operation. With respect to management, it has established the operating mechanism of independent accounting, and developed a comparatively perfect evaluation incentive system. The main mode of operation is students of a grade are divided as a unit to practice on-duty in our school, and arrange students to operate by rotation according to studio post. They need to complete a complete business operation process through "ordering, order confirmation, order record, logistics and distribution, customer service" and other links. Freshmen of 2016 shall learn basic knowledge in the classroom environment to lay theoretical basis for on-duty practice in the future.

With respect to corporate culture, our school sets this training base according to the organizational structure of Lianyungang Xiangtian Technology Co., Ltd. in the construction of e-commerce training base, and invites senior staff to act as business instructor of students. Each department is constituted by professional teachers, enterprise senior staff, and students. Conduct mutual exchange between colleges and enterprises, make young teachers to practice in enterprises by taking a temporary post; invite senior engineer from enterprises to school to deliver professional academic report; if enterprises cooperate with colleges, their scientific research projects or product development level will be enhanced through horizontal topics; set up school-enterprise professional teaching guidance committee to jointly develop the professional talent cultivation program, practical teaching system and training base construction that not only meet the teaching reality of our school but also highlight the enterprise demands and training base construction. For example, the e-commerce teachers of our school participate in-depth into the enterprises that cooperate with colleges, and set up a set of "genuine" training projects and teaching 
materials that dominates "working and learning combination" of e-commerce major of our school, which runs through the whole teaching process of e-commerce major. This will not only enable students to practice in genuine e-commerce operation environment, so that they can "learn while working", but also enable enterprises to benefit from the project, and students can also get into their role of "employee" in advance, to improve students' employability, ensure to use quality teaching materials in the classroom, break the bottleneck of higher vocational colleges for running a school, and play an important role of reference for taking a road of characteristic major and characteristic way for running school.

\section{References}

[1] Luo Yali. Exploration on "Introducing Enterprises into School and School-enterprise Cooperation" for Constructing E - commerce Professional Practice Base in Higher Vocational Colleges Jointly [J]. Chi Zi, 2012(10)

[2] Wang Guoling. Exploration of "Introducing Enterprises into School and School-enterprise Cooperation" for Constructing Training Base of E-commerce Major in Higher Vocational Colleges Jointly [J]. E-commerce, 2011(10)

[3] Zheng Shuyuan. On the Construction of E-commerce Training Teaching System in Higher Vocational Colleges [J]. Journal of Taiyuan Urban Vocational College, 2010, No. 09

[4] Wang Hui. On Construction of E - commerce Innovation and Entrepreneurship Practice Platform in Higher Vocational Colleges [J]. Vocational \& Technical Education Forum, 2011, No.29

[5] Jin Tao. Study on E-commerce Talent Cultivation Mode based on Practical Teaching of Enterprise College [J]. Management \& Technology of SME (version of end of the month), 2011, No.06

[6] Liu Jincun. Joint Negotiation, Determination and Collaboration: Exploration on "Government-school Cooperation" Operation Mechanism Innovation [J].Jiangsu Higher Education, 2013(1):66-67

[7] Li Bingqing. Analysis of New Think Tank Construction Path in Colleges under New Normal Vision [J]. Journal of Jiamusi Vocational Institute, 2016(11): 168

[8] Li Yanqiu. Study on Long-term Mechanism of School-enterprise In-depth Cooperation in Higher Vocational Colleges under the Linkage Mode of Government, School, and Enterprise Cooperation [J]. Contemporary Vocational Education, 2015(11): 21-23

[9] Lei Wusheng, Wu Jianhua, Yan Zhiming. Research on and Analysis of "School-government Cooperation" for Cultivating New Professional Farmers [J]. Vocational \& Technical Education Forum, 2014(30): 59-62

[10] Wu Jinhua. Study on Full Process Entrepreneurship Education Mode under the Background of School-government Cooperation [J]. Reading and Writing, 2014(8): 